\title{
Acute kidney injury associated with COVID-19: another extrapulmonary manifestation
}

\author{
Luis Barros Camargo • Iván Darío Quintero Marzola ${ }^{2,3}$ (1) Juan Carlos Cárdenas Gómez ${ }^{2}$. \\ Leidy Tatiana Mendoza Daza ${ }^{2,4}$. Loraine Quintana Pájaro ${ }^{2,5}$
}

Received: 29 April 2020 / Accepted: 11 May 2020 / Published online: 28 May 2020

(c) Springer Nature B.V. 2020

\section{Dear Editor,}

Since December 2019, the world has been learning about a new coronavirus, SARS-CoV2, a virus associated with COVID-19 disease. A characteristic of this coronavirus is damage to the pulmonary interstitium and its consequent viral pneumonia; however, it is known that it is capable of damaging other systems and organs [1].

Several studies have shown evidence of the presence of kidney damage and its relationship with mortality. One of these is the multicenter and retrospective study by $\mathrm{Li}$ et al., which involved 193 patients hospitalized for COVID19 , finding frequent alterations in the tests on admission: $59 \%$ presented with proteinuria, hematuria in $44 \%$, BUN elevated in $14 \%$ of patients, hypoalbuminemia in $58 \%$ and $10 \%$ had elevated serum creatinine. Findings highlight the importance of tracking in examinations from admission to the emergency department or hospitalization. In addition, in this study, significant differences in serum creatinine ( $\mathrm{SCr}$ ), BUN, proteinuria and hematuria were observed among severe and non-serious patients infected with SARS Cov-2 and higher levels were observed in the deceased, associated with a risk factor 5.3 times higher for mortality than in

Iván Darío Quintero Marzola

Iquinteromarzola11@gmail.com

1 Nephrologist Fundación Universitaria de Ciencias de la Salud, Bogotá, Colombia

2 Centro de Investigaciones Biomédicas (CIB), Línea Cartagena Neurotrauma Research Group, Universidad de Cartagena, Cartagena, Colombia

3 Facultad de Medicina, Universidad Libre, Barranquilla, Atlántico, Colombia

4 Facultad de Medicina, Universidad la Sabana, Bogotá, Colombia

5 Facultad de Medicina, Universidad de Cartagena, Cartagena, Colombia patients without acute kidney injury (AKI) [2]. Similar findings were found in the prospective cohort study involving 701 patients, published by Cheng et al., who analyzed the proportional risks of renal symptomatology finding: elevated BUN (HR 7.15, 95\% CI 4.92-10.39), elevated SCr (HR $2.99,95 \%$ CI $2.00-447)$, hematuria $1+$ (HR $4.64,95 \%$ CI 2.24-9.62) and proteinuria $1+(\mathrm{HR} 4.12,95 \%$ CI 1.97-8.62) all with statistically significant results [3].

Conversely, Wang et al. did not find progression to AKI in patients with COVID-19, reporting that 5 of 116 patients studied had pre-existing chronic kidney disease (CKD), without progression to AKI. Of the patients without CKD, $7 \%$ reported albuminuria and $10.8 \%$ mild increases in BUN and serum creatinine. However, the alterations were corrected in both cases and there was no progress to acute kidney injury. Of this cohort studied, 6.3\% (seven patients) died, none had AKI or CKD [4].

It is known that the virus uses the angiotensin II-converting enzyme (ACE2) as a receptor for its entry into the cell; however, the transmembrane serine 2 protease is fundamental for this process since it breaks the bond between the virus protein $\mathrm{S}$ and ECA2 allowing the release of peptides by the virus that facilitate membrane fusion and thus infection of the host cell [5]. Studies have demonstrated the expression of ECA2 and TMPRSS2, a gene encoding serine 2 transmembrane protease, in podocytes and cells of the proximal rectus tubule, important structures in protein filtration and urine in general, which may be affected by the harmful effects of the virus on them, leading to alterations in renal function tests and acute renal failure [5]. The expression of these enzymes assumes that the cells of the kidney epithelium and its functional unit are targets of infection and replication of SARS CoV-2, theory that is supported by the detection of virus antigens in postmortem samples of renal tissue of COVID-19 patients who presented with $\mathrm{AKI}$ and by the presence of the virus in the urine of infected individuals $[6,7]$. 
In addition to the cytopathic effect, a severe immunological reaction would be triggered, leading to infiltration of macrophages and lymphocytes into the renal tubular interstitium as well as fibrosis and alterations in the microvasculature with their consequent tubular damage; therefore, acute tubular necrosis and AKI are produced not only due to the direct effect of the virus, but also due to the immune reaction produced [6].

Likewise, the renin-angiotensin-aldosterone system is also altered by SARS-CoV-2 by massively occupying ACE2, raising blood levels of angiotensin II, which has been associated with viral load [8], this increase could mean in a vasoconstriction of the afferent artery of the nephron, causing a decrease in blood flow in the nephron and therefore alterations in the glomerular filtration rate; however, this theory needs studies for its validation. Furthermore, blood volume and sodium levels would be increased, not only by the increased activity of aldosterone due to the increase of angiotensin II, but also by the decrease of angiotensin 1-7, a product of angiotensin II degradation by ECA2, which has a natriuretic and vasodilator effect [8].

It is presumed that the virus reaches the renal parenchyma through the bloodstream, since it has been shown that approximately $15 \%$ of patients with renal injury present the RNA of the virus in the blood [9].

On the other hand, AKI induced by SARS-CoV-2 also affects patients with previous renal disorders; studies claim that CKD is associated with severe disease in those infected with COVID-19 with an OR of 3 (95\% CI 1.09-8.47) [10], as well as $25 \%$ of elderly patients with pre-existing basic diseases, higher risk population, died by COVID-19, were complicated by presenting AKI in a study published by Chen et al. [11]. In addition to this, a series of cases of seven patients with a history of renal transplantation and COVID-19 respiratory infection in South London showed that these people usually present atypical symptoms and more complications than in immunocompetent individuals; since four of these patients required ICU and one died [12,13], it is therefore recommended in some documents that immunosuppressive management should be minimized or discontinued for a certain time [14].

In conclusion, the kidney and its functional unit are targets of SARS-CoV-2, producing extrapulmonary symptoms and even being a risk factor for developing severe disease and mortality. Therefore, it is suggested that special attention be paid to the evolution of renal function tests and an action aimed at the protection of renal function since the admission of patients with COVID-19.

\section{References}

1. Perico L, Benigni A, Remuzzi G (2020) Should covid-19 concern nephrologists? Why and to what extent? The emerging impasse of angiotensin blockade. Nephron 144(5):213-221. https://doi. org/10.1159/000507305

2. Li Z, Wu M, Yao J, Guo J, Liao X, Song S et al (2020) Caution on kidney dysfunctions of COVID-19 patients. medrxiv. https:// doi.org/10.1101/2020.02.08.20021212

3. Cheng Y, Luo R, Wang K, Zhang M, Wang Z, Dong L et al (2020) Kidney disease is associated with in-hospital death of patients with COVID-19. Kidney Int 97(5):829-838. https://doi. org/10.1016/j.kint.2020.03.005

4. Wang L, Li X, Chen H, Yan S, Li D, Li Y et al (2020) Coronavirus disease 19 infection does not result in acute kidney injury: an analysis of 116 hospitalized patients from Wuhan, China. Am J Nephrol 430060:1-6

5. Pan XW, Xu D, Zhang H, Zhou W, Wang LH, Cui XG (2020) Identification of a potential mechanism of acute kidney injury during the COVID-19 outbreak: a study based on single-cell transcriptome analysis. Intensive Care Med. https://doi.org/10.1007/ s00134-020-06026-12-4

6. Diao B, Feng Z, Wang C, Wang H, Liu L, Wang C et al (2020) (2020) Human kidney is a target for novel severe acute respiratory syndrome coronavirus 2 (SARS-CoV-2) infection. medRxiv 2:20031120

7. Naicker S, Yang CW, Hwang SJ, Liu BC, Chen JH, Jha V (2020) The Novel Coronavirus 2019 epidemic and kidneys. Kidney Int 97(5):824-828. https://doi.org/10.1016/j.kint.2020.03.001

8. Centro de coordinación de alertas y emergencias sanitarias. Ministerio de Sanidad de España. Enfermedad por coronavirus, COVID-19 [Internet]. 2020. https://www.mscbs.gob.es/profesiona les/saludPublica/ccayes/alertasActual/nCov-China/documentos /20200417_ITCoronavirus.pdf. pp 1-37

9. Larsen CP, Bourne TD, Wilson JD, Saqqa O, Sharshir MA (2020) Collapsing glomerulopathy in a patient with coronavirus disease. Kidney Int Reports. https://doi.org/10.1016/j.ekir.2020.04.002

10. Henry BM, Lippi G (2020) Chronic kidney disease is associated with severe coronavirus disease 2019 (COVID-19) infection. Int Urol Nephrol 2019(123456789):9-10

11. Chen T, Wu D, Chen H, Yan W, Yang D, Chen G et al (2020) Clinical characteristics of 113 deceased patients with coronavirus disease 2019: retrospective study. BMJ 368:m1091

12. Seminari E, Colaneri M, Sambo M, Gallazzi I, Di Matteo A, Roda S et al (2020) SARS Cov-2 infection in a renal-transplanted patient: a case report. Am J Transplant. https://doi.org/10.1111/ ajt. 15902

13. Izzedine H, Jhaveri KD, Perazella MA (2020) COVID-19 therapeutic options for patients with kidney disease. Kidney Int. https ://doi.org/10.1016/j.kint.2020.03.015

14. Banerjee D, Popoola J, Shah S, Ster IC, Quan V, Phanish M (2020) COVID-19 infection in kidney transplant recipients. Kidney Int. https://doi.org/10.1016/j.kint.2020.03.018

Publisher's Note Springer Nature remains neutral with regard to jurisdictional claims in published maps and institutional affiliations. 